\title{
A NEW SPECIES OF PYGMY-OWL (STRIGIDAE: GLAUCIDIUM) FROM THE PACIFIC SLOPE OF THE NORTHERN ANDES
}

\author{
MARK B. RoBbins ${ }^{1,3}$ AND F. GARY STILES ${ }^{2}$ \\ ${ }^{1}$ Division of Ornithology, Natural History Museum, University of Kansas, Lawrence, Kansas 66045, USA; and \\ ${ }^{2}$ Instituto de Ciencias Naturales, Universidad Nacional de Colombia, Apartado 7495, Bogota, Colombia
}

\begin{abstract}
We describe a new species of pygmy-owl that is restricted to very wet cloud forest at 1,400 to 2,000 m in elevation along the Pacific slope of the western Andes of Colombia and Ecuador. This taxon had been long overlooked as a result of its morphological similarity and geographic proximity to the Andean Pygmy-Owl (Glaucidium jardinii), but it is vocally very distinct and exhibits subtle but consistent morphological differences as well. Vocally, the new species is most similar to the Costa Rican-Panamanian form G. costaricanum and to the nominate subspecies of Northern Pygmy-Owl (G. gnoma), but again, consistent differences exist in vocalizations and morphology. Glaucidium costaricanum has long been considered a subspecies of $G$. jardinii, but at least one recent author treated it as a subspecies of G. gnoma. Genetic, vocal, ecological, and morphological data indicate that G. costaricanum should be elevated to species level, and it along with the new species are considered allospecies within the Northern Pygmy-Owl superspecies complex. Received 20 July 1998, accepted 2 December 1998.
\end{abstract}

RECENT STUDIES OF THE TAXONOMY of New World pygmy-owls (Glaucidium) have revealed that the diversity of this group has been grossly underestimated (Vielliard 1989, König 1991, Heidrich et al. 1995, Howell and Robbins 1995, Robbins and Howell 1995). This is not surprising given that morphological and vocal variation in these owls are on the same order as the equally cryptic, but better-studied Empidonax flycatchers (Stein 1958, Johnson 1980, Lanyon and Lanyon 1986, Johnson and Marten 1988). However, unlike the diurnal, relatively numerous, and highly vocal Empidonax, pygmy-owls often occur in low densities in tall, humid forest and are notoriously difficult to locate and collect.

On 27 August 1987, during an avifaunal inventory conducted by the Academy of Natural Sciences of Philadelphia and the Museo de Ciencias Naturales, Quito, Fred and Jody Sheldon and Robbins mist netted a male pygmyowl (ANSP 180178) along a Pacific-slope ridge of relatively pristine, humid subtropical forest at $1,550 \mathrm{~m}$ above the town of Mindo, provincia Pichincha, Ecuador. No definitive identification was made of the specimen at the time for lack of comparative material. The following year, however, Robbins recorded the voice and collected a male and female (ANSP 181043-4) at $1,725 \mathrm{~m}$ in humid subtropical forest on the $\mathrm{Pa}$ -

\footnotetext{
${ }^{3}$ E-mail: mrobbins@falcon.cc.ukans.edu
}

cific slope near the Colombia/Ecuador border (ca. $4 \mathrm{~km}$ SSW of Chical, provincia Carchi; $00^{\circ} 54^{\prime} \mathrm{N}, 78^{\circ} 12^{\prime} \mathrm{W}$ ) that unequivocally belong to the same taxon as the bird netted near Mindo the previous year. Although Robbins recognized that the voice of this undescribed taxon was distinct from that of the upper-elevation Andean Pygmy-Owl (G. jardinii), its affinities remained unclear. Robbins sent tape recordings of the Chical birds to Stiles, who recognized that they were nearly identical to those of a bird he had recorded and collected on 3 June 1992 in subtropical cloud forest at Alto de Pisones, Risaralda, Colombia (Fig. 1). Stiles also noted that the voice of these owls was most similar to that of the isolated Costa Rica/Panama form G. jardinii costaricanum, and in fact had tentatively classified his Colombian bird as costaricanum on that basis. This form had not been considered even subspecifically distinct from nominate jardinii of the high Andes until Kelso's (1937) evaluation. Since that time, costaricanum has been treated as a subspecies of jardinii (Peters 1940, Ridgely and Gwynne 1989, Stiles and Skutch 1989, Sibley and Monroe 1990, AOU 1998). However, based on molecular studies, Heidrich et al. (1995) treated costaricanum as a subspecies of the Northern Pygmy-Owl (G. gnoma) of North America, a possibility adverted on the basis of voice by König (1991). Meanwhile, Robbins located 


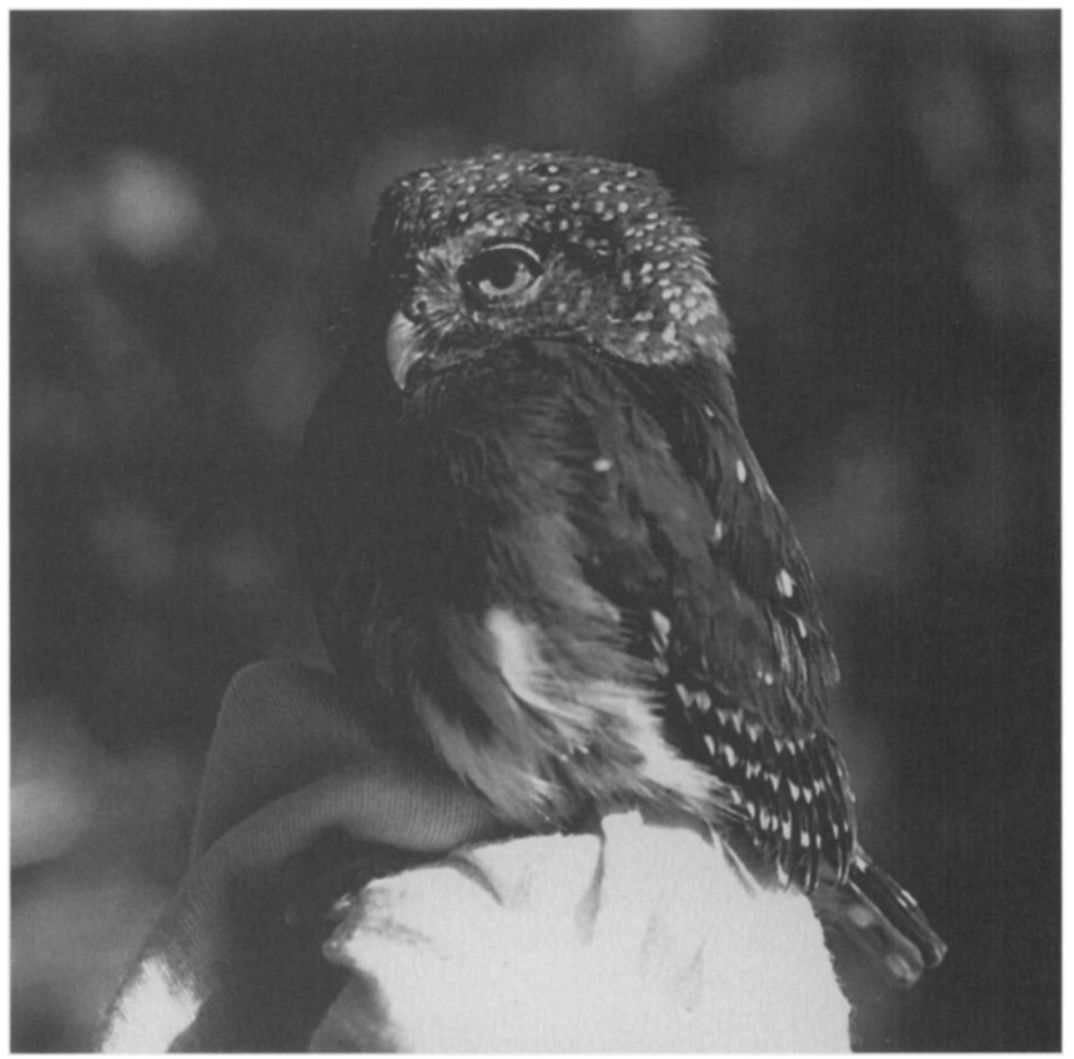

FIG. 1. Adult male Glaucidium nubicola from Alto de Pisones, Colombia (ICN 31200). Note the mininal or complete lack of pale spotting or barring on the back, sides of the chest, and flanks that distinguishes this species from the similar appearing G. costaricanum, G. jardinii, and G. bolivianum. Photograph by F. Gary Stiles.

three additional specimens of the new South American taxon, all identified as nominate jardinii, in North American museums.

Heidrich et al. (1995) compared the mitochondrial DNA sequences (cytochrome- $b$ gene) of the Mindo bird with those of a number of other Glaucidium taxa, including costaricanum. Their findings and further molecular work by Nathan H. Rice and Robbins (see below) confirmed that the Pacific-slope bird in fact represents a distinct, undescribed species and is most closely allied to the Northern Pygmy-Owl complex (including costaricanum) rather than to G. jardinii. We propose to call this new owl:

\section{Glaucidium nubicola sp. nov. Cloud-forest Pygmy-Owl}

Holotype.-Academy of Natural Sciences of Philadelphia, No. 181044, adult male (testes 3 $\times 2 \mathrm{~mm}$; no bursa of Fabricius), Ecuador, pro- vincia Carchi, approximately $4 \mathrm{~km} \mathrm{SSW}$ Chical, S side Quebrada San José of the Río Blanco, $00^{\circ} 54^{\prime} \mathrm{N}, 78^{\circ} 12^{\prime} \mathrm{W}$, elevation 1,725 m, 16 August 1988; collected by Mark B. Robbins. Recordings of voice deposited at the Library of Natural Sounds, Cornell Laboratory of Ornithology, Ithaca, New York (LNS 49158, 49185, 49187).

Diagnosis.-Typical Neotropical pygmy-owl in appearance, especially similar to temperate forms G. [gnoma] costaricanum, G. jardinii, and the recently described Yungas Pygmy-Owl (G. bolivianum; König 1991). The new owl averages heavier in body mass and has a shorter tail than the other taxa (Table 1), and it has much less extensive pale spotting or barring on the back, sides of the chest, and flanks than costaricanum, jardinii, and bolivianum. The black marks on the hindneck (i.e. the so-called "false eyespots") are bordered by white in all non-rufous individuals, in contrast with the rufous borders of costaricanum. See also Song. 


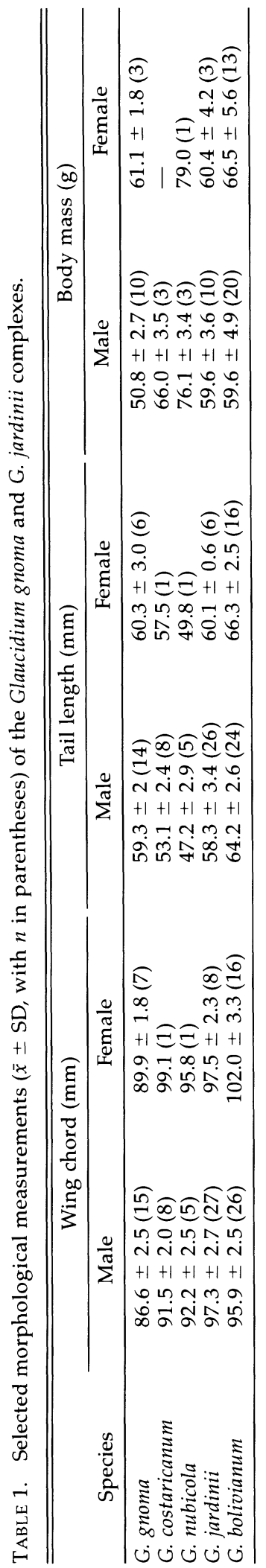

Description of holotype.-Capitalized color descriptions and numbers follow Smithe (1975, 1981). Crown, face, and auricular area brown (closest to Hair Brown 119A) with white spots bordered by Sepia (119). Concealed white nuchal collar bordered with Sepia (119). Back, scapulars, upperwing coverts, and rump dark brown (closest to Sepia 219) washed with dark rufous-brown. Scapulars and upperwing coverts with bold white spots, most tinged with pale rufous. Primaries and secondaries with less rufous-brown wash than dorsum and with conspicuous, irregularly shaped whitish spots (many with pale rufous tinge) on outer webs, and larger, concealed white spots on inner webs, forming an indistinct band. Tail blackish (closest to Sepia 119) with five incomplete white bands appearing as irregularly shaped spots. Chin, sides of upper throat, and center of chest white. Center of abdomen and crissum white with buffy brown wash. Center and lower part of throat dark brown (closest to Sepia 219). Sides of chest rufous brown (closest to Raw Umber 223, but with more rufous tinge) with a few inconspicuous white spots extending through the abdominal region as streaks. Abdominal streaks becoming darker in color (closest to Sepia 219). Irides yellow, bill greenish-yellow, tarsi and toes yellow, claws black. See cover for depiction of the holotype.

Measurements of holotype.-Wing chord (unflattened) $92.0 \mathrm{~mm}$, tail length $46.8 \mathrm{~mm}$, bill length (from cere to tip) $11.3 \mathrm{~mm}$, body mass $80 \mathrm{~g}$.

Etymology.-We have chosen the specific epithet nubicola, which is Latin for "cloud inhabiting," because the bird is restricted to very humid cloud forests.

Specimens examined: Skins.-Localities are depicted in Figure 2. Glaucidium nubicola: Colombia: Risaralda, Alto Pisones, Mistrató, 1,740 $\mathrm{m}, 05^{\circ} 25^{\prime} \mathrm{N}, 76^{\circ} 02^{\prime} \mathrm{W}, 1$ male (ICN 31200, Figure 1 ; see Acknowledgments for acronyms of institutions); Valle, San Antonio, 2,000 m, 03 ${ }^{\circ} 30^{\prime} \mathrm{N}$, 76 $38^{\prime} \mathrm{W}, 1$ male (MVZ 138178). Ecuador: Pichincha, 3 males (ANSP 181078; CMC 24953, 29972); Carchi, 1 male (ANSP 181044 [holotype]), 1 female (ANSP 181043). In the following lists, locality names are given only to the level of state, province, or department. Glaucidium costaricanum: Costa Rica: San José, 2 males (UCR 2001; LSUMZ 52589); Cartago, 1 male (LSUMZ 153994), 1 female (AMNH 


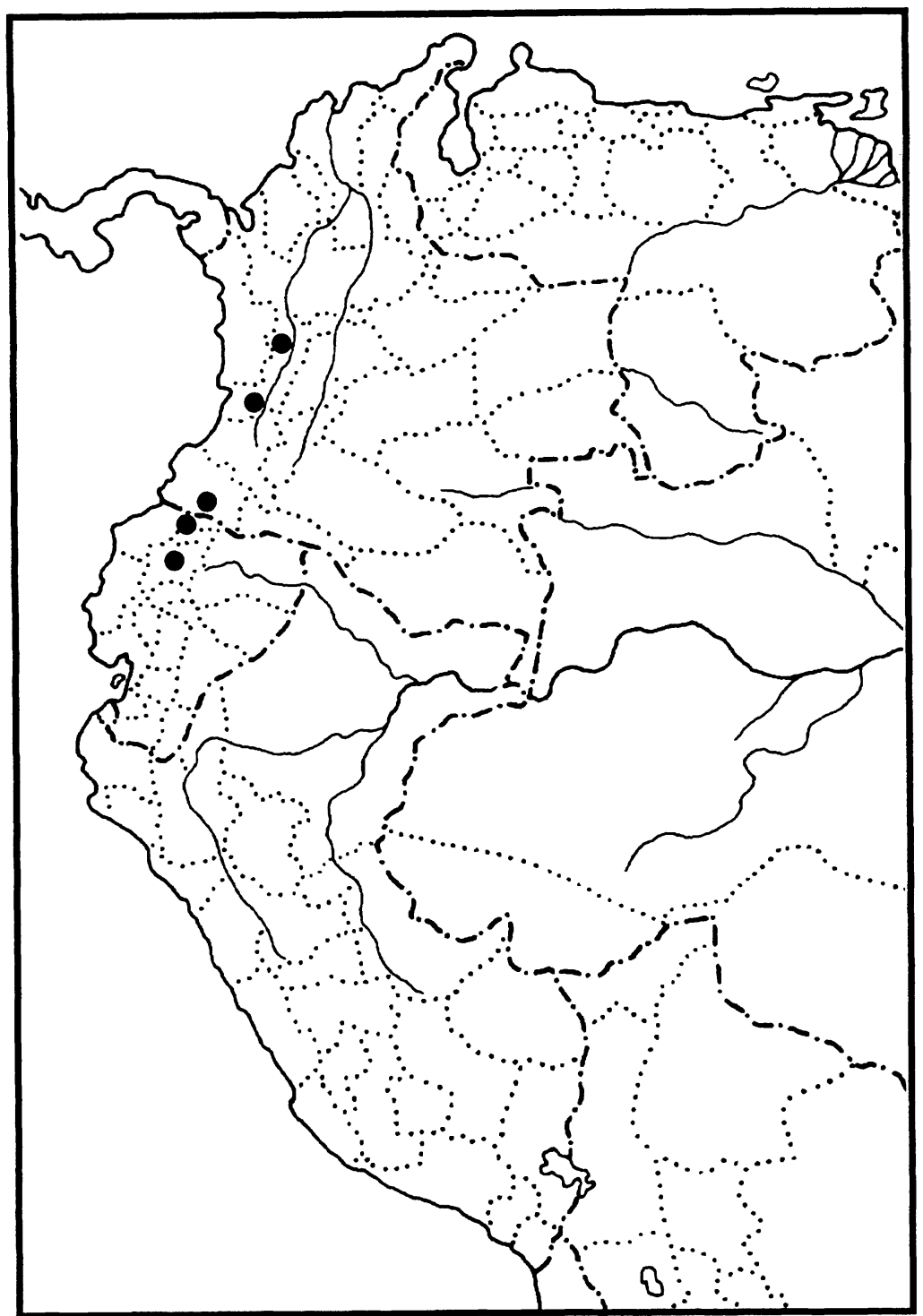

FIG. 2. Northwestern South America, showing localities at which Glaucidium nubicola has been recorded. The southernmost symbol represents three different sites in provincia Pichincha, Ecuador. See Specimens Examined for specific locality data.

485467); 1 unsexed (AMNH 801545). Panama: Chiriquí, 3 males (LSUMZ 160719; USNM 485737; AMNH 768851); unknown Panama locality, 1 male (USNM 154246). Glaucidium gnoma gnoma: Mexico: Chihuahua, 6 males, 4 females (MVZ 143683-4, 119358-9, 119360-1, 119364, 119378-9, 135144); Veracruz, 1 male (FMNH 187123); Coahuila, 1 male (KU 31582); Jalisco, 1 male (MVZ 115393); Michoacan, 6 males, 3 females (FMNH 102555-7, 102791-2; MVZ 115391-2, 150017; KU 35073). Glauci- dium jardinii: Colombia: Nariño, 1 male, 1 female (FMNH 287981, 249563); Cauca, 2 males, 1 female (ANSP 17383, FMNH 101287, 102214); Huila, 1 male (FMNH 102226). Ecuador: Carchi, 2 males (ANSP 184581, 184582); Imbabura, 2 males (LSUMZ 112509-10); Pichincha, 2 males (ANSP 66864, AMNH 485553); Napo, 1 male (AMNH 179926); Cotopaxi, 1 male (ANSP 183103); Zamora-Chinchipe, 1 male (ANSP 185159). Peru: Piura/Cajamarca, 7 males, 3 females (LSUMZ 75125, 97581-3, 87284-6, 
97578-80). Glaucidium bolivianum: Peru: Amazonas, 2 males, 2 females (LSUMZ 87287-8, 87291; ANSP 118137); San Martín, 1 male (LSUMZ 104450), 1 female (LSUMZ 104449); La Libertad, 3 males (LSUMZ 91699-701); Huánuco, 2 males, 3 females (FMNH 299047, 296610; LSUMZ 79676, 73828, 118959); Pasco, 5 males, 1 female (LSUMZ 128154-7, 105661,128158); Apurímac, 1 male (FMNH 299519); Ayacucho, 1 male, 1 female (LSUMZ 68817, 69362); Cuzco, 3 males, 1 female (FMNH 299517, 311744, 311742; LSUMZ 80431); Puno, 1 male, 2 females (98096-8). Bolivia: La Paz, 4 males, 4 females (LSUMZ 90534-6, 101693-7); Cochabamba, 3 males (LSUMZ 123557-8, 123560). The holotype of G. jardinii, from the Pichincha area, Ecuador, apparently is no longer extant (E. Pasquet pers. comm., Muséum National d'Histoire Naturelle, Paris).

Specimens examined: Tape-recordings.-Glaucidium nubicola: Colombia: Risaralda, Alto de Pisones (F. G. Stiles); Nariño, Reserva Río Nambí, $1,300 \mathrm{~m}, 01^{\circ} 18^{\prime} \mathrm{N}, 78^{\circ} 05^{\prime} \mathrm{W}$ (P. Coopmans). Ecuador: Pichincha, Mindo (R. Jonsson); Carchi (holotype; LNS 49158, 49185, 49187). Glaucidium costaricanum: Costa Rica: Cerro de la Muerte (UF 884A). Glaucidium gnoma: Mexico: Sinaloa (LNS 200201, 53150); Colima (LNS 57735-7); Coahuila (Hardy et al. 1990); Nuevo León (LNS 53441, 56681). Glaucidium jardinii: Colombia: Cundimarca (FSU 1352, 1354). Ecuador: Loja (LNS 57016) Zamora-Chinchipe (LNS 78948). Glaucidium bolivianum: Peru: La Libertad, Cumpang (LNS 17332, 17347); Cuzco (R. A. Behrstock); Pasco (LNS 40140, 40144, 40162). Spectrograms in König (1991) of the above taxa were also examined. Skins and vocal material examined of Subtropical (G. parkeri), Colima (G. palmarum), Central American (G. griseiceps), Amazonian (G. hardyi), and Least (G. minutissimum) pygmy-owls are listed in Robbins and Howell (1995).

\section{REMARKS}

Individual variation.-The two oldest (ca. 60 years) specimens (CNC 24953, 29972) of nubicola are somewhat paler than the more recent specimens, likely a result of fading. The Valle, Colombia, bird (MVZ 138178) is very similar to the holotype but lacks suffusion of buffybrown wash on the abdomen and crissum. The Mindo male (ANSP 180178) differs from the holotype in having a more rufous-brown wash to the entire plumage. The Mindo female (ANSP 181043) has a more extreme rufous wash, matching rufous-morph individuals of $G$. jardinii and G. bolivianum, with more extensive spotting on its back than the other paratypes, forming irregular bands. Although ICN 31200 was not compared directly with the other paratypes, it agrees closely with the description of the holotype, differing in minor details of coloration as follows: dorsum nearest to Raw Umber (223), washed anteriorly and laterally with rufous-brown (near Mars Brown, 223A). Pale spotting on scapulars and remiges whitish, more or less strongly tinged with Pinkish Buff (121D) to pale rufous. Sides of breast rich brown (nearest Mars Brown, 223A), nearly immaculate; ventral streaks are blackish-brown centrally (Sepia, 219) shading through Mars Brown to Pinkish Buff (121D) on borders giving the impression of dark streaking on a buffy background; center of lower breast and abdomen white. Five pale tail-bands occur in all but the rufous-morph bird (ANSP 181043), which has six. Rufous morphs of most (all?) Glaucidium tend to have more tail bands than do brown or gray morphs (unpubl. data).

Song.-Like virtually all New World Glaucidium, the song of nubicola is composed of structurally simple notes best expressed as hollow whistles or toots. Although note structure is similar among taxa, distinct differences exist in internote length and interval both within and among superspecies groups (Howell and Robbins 1995). Because these two features have proven taxonomically informative, we used them to characterize pygmy-owl song patterns.

The length and spacing of notes clearly distinguish nubicola from costaricanum and gnoma (Table 2). The song of nubicola consists of notes of constant duration (notes average $161 \pm$ SD of $28.8 \mathrm{~ms}$ ), delivered in pairs (occasionally in trios). Within note pairs, intranote pauses averaged $207.9 \pm 18.0 \mathrm{~ms}$, whereas pauses between pairs (internote) averaged $344.8 \pm 21.0$ ms (Table 2). This distinctive pattern of paired whistles (Fig. 3A-C) serves as a putative synapormorphy of nubicola, costaricanum, and gno$m a$ and distinguishes this clade from all other Glaucidium (König 1991, Howell and Robbins 1995). Although Miller (1963) followed the standard taxonomic treatment of Andean pygmy-owls at that time (all high elevation birds 
TABLE 2. Selected song characters ( $\bar{x} \pm \mathrm{SD}$ in $\mathrm{ms}$ ) of montane pygmy-owls. Sample sizes are smaller than the number of individuals and songs studied because measurements were restricted to individuals vocalizing under natural circumstances (i.e. no playback) and for which recordings were sufficiently clear to permit accurate measurements.

\begin{tabular}{lccc}
\hline \multicolumn{1}{c}{ Species } & Internote interval & Note length & Intranote interval \\
\hline G. gnoma $(n=4)$ & $579.9 \pm 96.0$ & $106.2 \pm 9.2$ & $321.6 \pm 36.5$ \\
G. costaricanum $(n=1)$ & 276.2 & 98.6 & 185.0 \\
G. nubicola $(n=2)$ & $344.8 \pm 21.0$ & $161.0 \pm 28.8$ & $207.9 \pm 18.0$ \\
G. jardinii $(n=3)$ & $202.4 \pm 30.0$ & $116.0 \pm 11.7$ & - \\
G. bolivianum $(n=3)$ & $548.0 \pm 72.1$ & $196.7 \pm 34.6$ & - \\
\hline
\end{tabular}
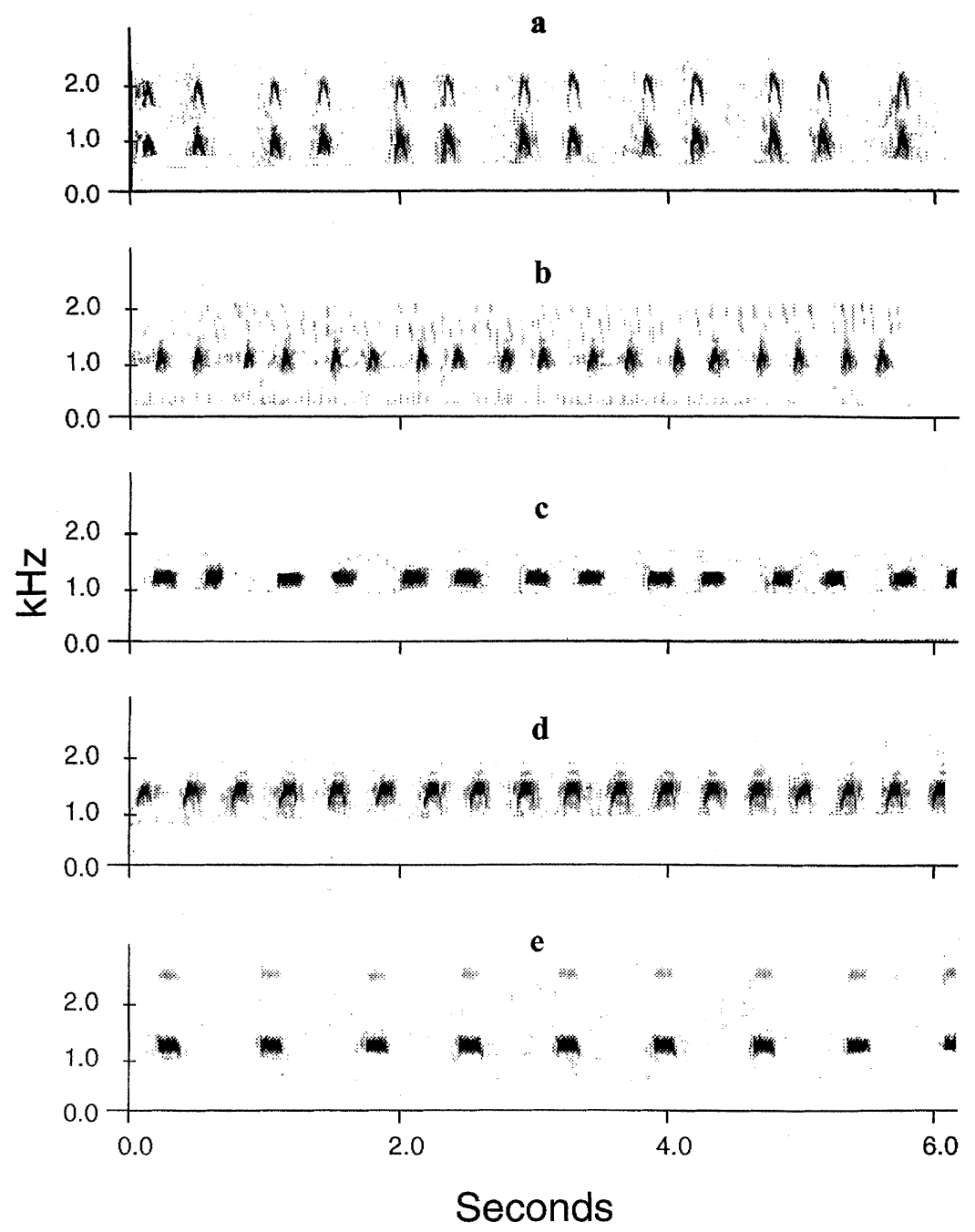

FIG. 3. Sound spectrograms of primary song of selected pygmy-owls. Y-axis represents frequency in kilohertz $(\mathrm{kHz})$. X-axis represents time in seconds. (A) Glaucidium gnoma: Mexico, Colima (LNS 57735), recorded by D. Delaney. (B) G. costaricanum: Costa Rica, Cerro de la Muerte (FSM 884A), recorded by Stiles. (C) G. nubicola: Ecuador, provincia Pichincha, recorded by R. Jonsson. (D) G. jardinii: Ecuador, provincia Zamora-Chinchipe (LNS 78948), recorded by Robbins. (E) Glaucidium bolivianum: Peru, departamento Cuzco, recorded by R. Behrstock. 
considered as jardinii), he astutely noted that the San Antonio, Colombia, birds had a song similar to nominate gnoma. Although nubicola was long confused with jardinii on the basis of morphological similarity and geographic proximity, its note pattern is clearly aligned with the gnoma group, and not the jardinii complex (i.e. jardinii and bolivianum). Members of the latter group typically give songs with evenly spaced notes (Fig. 3D-E).

Morphometrics.-The Cloud-forest PygmyOwl has a significantly shorter tail and heavier body mass than gnoma and costaricanum and members of the Andean pygmy-owl complex (Table 1).

Distribution.-Glaucidium nubicola may occur continuously along the Pacific slope of the Andes from northwestern Colombia (Antioquia) to southwestern Ecuador near the Peruvian border, as do many other subtropical taxa of similar cloud-forest habitats (Chapman 1926, Robbins and Ridgely 1990). The known elevational range of G. nubicola is about 1,400 to $2,000 \mathrm{~m}$; above these elevations it is replaced by G. jardinii.

Habitat.-All seven sites (Fig. 2) where G. $n u$ bicola has been found are (or were) in wet primary cloud forest on steep slopes. The Mindo bird was netted about $2 \mathrm{~m}$ above the ground along a ridge in wet primary cloud forest. $\mathrm{Al}-$ though the forest near Gualea, only about 20 $\mathrm{km}$ north of Mindo, has been affected by deforestation, remnant patches on the steepest slopes indicate that it also held wet cloud forest (M. Robbins pers. obs.). Both Carchi birds were found in wet primary cloud forest on steep slopes. The vegetation and topography at Río Ñambí, Alto de Pisones, and Reserva Natural La Planada are apparently quite similar to the Ecuadorean localities (Salaman and Stiles 1996). At San Antonio, Valle, Colombia, Miller (1963) collected a singing male from about 45 $m$ up in the crown of a primary forest tree. Nevertheless, annual rainfall undoubtedly differs between Alto de Pisones and Mindo, given the negative gradient in rainfall north to south along the Colombia and Ecuador Pacific slope (IGAC 1989, Gómez 1990).

Pygmy-owls in humid habitats typically have darker plumage coloration. Although nubicola and costaricanum are phylogenetically related to northern gnoma, their plumage color and patterns are remarkably similar to those of the more distantly related jardinii group, which has long obscured their systematic relationships. Presumably, these striking plumage similarities result from convergent adaptations for color-matching in very humid montane forests, whereas the duller, grayer gnoma principally inhabits drier pine-oak forests.

Breeding and molt.-All three recent Ecuador birds were taken in August; neither the two males nor the female had enlarged gonads (testes, $3 \times 2 \mathrm{~mm}$; ovary, $7 \times 3 \mathrm{~mm}$; ova, $<1 \mathrm{~mm}$ ), and all were in fresh plumage. The Mindo bird had no body molt, and both El Chical birds had moderate body molt, heaviest on the nape of the female; the male was replacing the right sixth rectrix, but otherwise all birds had fresh flight feathers. The nonbreeding status of these birds was also reflected in the infrequency of their vocalizations; no singing was heard at Mindo, and only occasional songs were heard at dawn at El Chical.

The male taken on 1 December at San Antonio, Colombia, had small $(3.5 \mathrm{~mm})$ testes and exhibited no molt (Miller 1963). The Alto de Pisones specimen from 4 June had testes $6.5 \times 4$ $\mathrm{mm}$, no molt, and was in fairly fresh plumage. At this locality on 1 to 3 June 1992, Stiles heard an individual singing persistently in the immediate vicinity of the collection site, as well as persistent singing from a ridgetop some $300 \mathrm{~m}$ away on 14 to 17 April 1993; on 16 April, a bird at this site responded strongly to Stiles's whistled imitation, countersinging and approaching to within $10 \mathrm{~m}$. Much less persistent singing was noted by Stiles in late June 1991 at La Planada; on three mornings on the same ridgetop in early July 1992, he heard only one short bout of song. For these reasons, we infer that $G$. nubicola probably breeds principally between February and June. Given that the peak breeding season of small birds at La Planada occurs in the brief dry season in June and July (G. Cantillo pers. comm., G. Stiles pers. obs.), earlier breeding by G. nubicola may permit young to fledge at a time when potential prey (fledglings of small birds) are most abundant.

Behavior and ecology.-Similar to other humid forest pygmy-owls, almost nothing is known about the natural history of G. nubicola. Most of the handful of observations of such Glaucidium are of birds being mobbed by passerines; in fact, Miller (1963) watched hummingbirds and tanagers mobbing a singing male nubicola for 
90 min. About mid-morning on 9 August, the nonvocalizing El Chical female (ANSP 181043) was flushed from her perch several meters above the ground in moderately dense vegetation along a steep forest trail. Along the same trail during mid-morning on 16 August, the nonvocalizing male holotype flushed from vegetation and flew to a perch about $3 \mathrm{~m}$ above the ground.

The bird from Mindo had insect fragments in its stomach, and the stomach of the female from El Chical was empty. The holotype had insect fragments and a small lizard, about $55 \mathrm{~mm}$ in length, in its stomach. The stomach of the San Antonio male held orthopterans and one hemipteran (Miller 1963). The Alto de Pisones bird was captured in a mist net along a sharp ridge crest, and apparently was attracted by distress calls of an Ornate Flycatcher (Myiotriccus ornatus) in the net. This pygmy-owl also had a $3.5-\mathrm{cm}$ cicada in its stomach. Hence, $n u-$ bicola appears to have the mixed diet of invertebrates and small vertebrates typical of the genus.

Although members of different species groups (Robbins and Howell 1995, Rice and Robbins unpubl. data), the west-slope G. nubicola appears to be replaced ecologically on the eastern slope of the Andes by G. parkeri. Both have been recorded in the same elevational range (ca. 1,400 to $2,000 \mathrm{~m}$; both likely occur lower) and are replaced by $G$. jardinii above 2,000 m.

Systematic affinities.-Several nocturnal species are renowned for their limited plumage differentiation, even among distantly related taxa (e.g. caprimulgids and Otus). Perhaps even more than in these latter groups, Neotropical pygmy-owls show minimal differentiation among taxa in plumage color and pattern and body size. However, this lack of plumage divergence is accompanied by consistent variation among taxa in the patterns and tempo of primary vocalizations. Indeed, quantitative studies of pygmy-owl vocalizations (König 1991, Howell and Robbins 1995) provided the first indications that speciation in these owls had been grossly underestimated.

With the advent of molecular tools, relationships among these taxa are being further elucidated. Heidrich et al. (1995) examined 300 base pairs of the mitochondrial cytochrome- $b$ gene in selected pygmy-owl taxa, including the nubicola from Mindo (ANSP 180178; =frozen tissue number LSUMZ 12188). These authors demonstrated (Heidrich et al. 1995: figure 35) that the closest living relatives of nubicola are costaricanum (=their "gnoma") and gnoma (=their "californicum" from British Columbia, Canada) and not jardinii. Levels of genetic differentiation among these taxa suggested that all three should be treated as species, a conclusion supported by the vocal data (see above). Inclusion of additional taxa and analyzing 450 base pairs of the cytochrome- $b$ gene have corroborated and extended these findings (N. H. Rice and Robbins unpubl. data). The latter analyses included nominate gnoma (from Michoacan and Oaxaca, Mexico), an additional sample of costaricanum (LSUMZ frozen tissue 28887, Panama), and a nubicola (feathers from the above MVZ 138178) that Heidrich et al. (1995) lacked. Preliminary results indicate that these three taxa form a well-supported and resolved clade ( $74 \%$ of 500 bootstrap replications). Nominate gnoma was the sister taxon to costaricanum in $99 \%$ of 500 bootstrap replications, with $n u$ bicola as sister to the gnoma/costaricanum clade.

The molecular data, coupled with morphological differentiation, vocal differences, distinct habitat preferences, and geographic isolation meet the requirements for species under the phylogenetic species concept (Cracraft 1983, Zink and McKitrick 1995). From a conservation perspective, the significant differences in these characters also qualify these taxa as evolutionary significant units (Ryder 1986, Moritz 1994).

Because these differentiated populations are allopatric, their classification under the biological species concept (Mayr 1963, 1969) is ambivalent because there is no indication on how individuals would interact if they came into contact. Because molecular data indicate that costaricanum and gnoma are sister taxa, we focus on their potential interaction. First, even if costaricanum and gnoma came into close geographic proximity (the closest populations are separated by about $550 \mathrm{~km}$ ), their dramatic ecological differences would preclude gene flow; nominate gnoma is primarily an inhabitant of drier pine-oak habitat, whereas costaricanum is found in wet montane cloud forest. Second, even if they were to come into contact in a montane ecotone, we predict that the dramatic plumage and size differences (Table 1; note es- 
pecially differences in body mass) would prevent or impede hybridization. Plumage color and pattern and morphological differentiation between costaricanum and gnoma are greater than is found between species belonging to different superspecies complexes. Indeed, we reemphasize that until recently costaricanum was considered to be an undifferentiated form of the distantly related $G$. jardinii complex. Finally, as pointed out by Howell and Robbins (1995), consistent differences exist in internote length and interval among Glaucidium species; those observed between costaricanum and nominate gnoma were about eight times more pronounced than those between nominate gnoma and the distantly related G. bolivianum (Table 2). Except for plumage coloration (see above), molecular, vocal, and morphological differentiation between nubicola and costaricanum are equal or greater than between costaricanum and nominate gnoma (Heidrich et al. 1995; Tables 1 and 2). Thus, we believe these three taxa should be considered species under any species definition.

We recommend the English name Costa Rican Pygmy-Owl for G. costaricanum. Furthermore, dramatic differences in voice among nominate G. gnoma, G. g. californicum, and G. g. hoskinsii suggest that at least three species should be recognized within the current Northern Pygmy-Owl (Phillips et al.1964, Hardy et al. 1990, König 1991, Heidrich et al. 1995, Howell and Webb 1995). Although these authors have suggested various taxonomic treatments for the forms currently within gnoma, it seems premature to make changes given the apparent vocal variation among forms in the United States (see Howell and Webb 1995). Molecular and vocal work in progress should clarify species limits within gnoma (R. C. Faucett pers. comm.). At present, we consider the G. gnoma complex to comprise a superspecies with at least three allospecies: nubicola, costaricanum, and gnoma, leaving open the question of recognition of additional species among the forms currently included within the latter taxon.

Biogeography.-The ancestor of these taxa probably inhabited the moist forested slopes of the northern Andes during the late Pliocene and early Pleistocene. With the permanent formation of the Middle American landbridge three to five million years ago (Malfait and Dinkleman 1972, Pindell and Dewey 1982), we surmise that the gnoma/costaricanum/nubicola ancestor expanded from the northern Andes into Central America during a glacial period when cooler climate lowered the elevational limits of montane forest life zones. Warming during an ensuing interglacial period restricted the Central American birds to the highest mountains of the Cordillera de Talamanca of Costa Rica and Panama and the Cordillera Central of Costa Rica. Subsequent glacial cycles may have permitted this population to expand northward, occupying the mountains of northern Central America and Mexico and eventually North America proper. An additional recent example of the long-recognized faunal affinity between the Costa Rica-Chiriquí highlands and the western Andes (Chapman 1917, 1926; Slud 1964) is the recently described Chocó Vireo (Vireo masteri) of the western Andes, whose closest living relative is probably the Yellow-winged Vireo ( $V$. carmioli) of the Costa Rica-Chiriquí highlands (Salaman and Stiles 1996).

Conservation.-Western Ecuador has suffered heavy deforestation during the past 50 years, with only $15 \%$ of the original lowland and montane forests remaining by the late 1980 s (see Dodson and Gentry 1991). The type locality surely has been denuded completely, because most of the slopes already had been cleared when Robbins et al. worked the site in 1988, and loggers with chainsaws were rapidly felling the remaining patches of forest. In Ecuador, the upper reaches of the Reserva Ecológica Cotocachi-Cayapas, provincia Imbabura; nearly all of the private 3,000 ha of Reserva Biológica Los Cedros, provincia Esmeraldas/ Imbabura; and the lower portions of the private 4,500 ha Reserva Maquipucuna, provincia Pichincha (Best et al. 1996) contain rather pristine habitat for nubicola and several other threatened and near-threatened bird species (Collar et al. 1992, Stattersfield et al. 1998).

Although human encroachment on the Pacific slope of Colombia has been slower than at other Andean sites because of high rainfall, deforestation rates nonetheless have increased dramatically in the past two decades. Major road construction in western Colombia is now providing access to once remote areas and is resulting in the same scenario that led to the deforestation of western Ecuador (Salaman and Stiles 1996). Viable populations of nubicola 
should occur in at appropriate elevations in the following Colombian reserves: Parque Nacional Los Farallones, Valle; and Parque Nacional Munchique, Cauca; Río Nambí Community and La Planada Nature Reserves, Nariño.

\section{ACKNOWLEDGMENTS}

We are indebted to Tracy Pedersen for the exquisite frontispiece. Bob Behrstock, Paul Coopmans, and Robert Jonsson generously shared their pygmyowl recordings. Nathan Rice provided relevant molecular data regarding this group. Carla Cicero and Ned Johnson kindly furnished copies of Alden Miller's field notes at the MVZ. Neal Woodman measured a specimen of costaricanum in the Costa Rican museum. We thank Eric Pasquet of Museum National d'Historie Naturelle, Paris, for determination of the status of the jardinii holotype. ANSP inventory work was conducted in conjunction with the Museo Ecuatoriano de Ciencias Naturales, Quito. The Ministerio de Agricultura, Quito, provided authorization for work in Ecuador. Stiles's field work at Alto Pisones was conducted under the auspices of a contract to the Insituto de Ciencias Naturales (ICN) for biological inventories in Risaralda from the Corporación Autónoma Regional de Risaralda; Gonzalo Andrade, Diana Mora, Milton Muñoz, and Carlos Alberto Venegas provided assistance and companionship in the field. Ned Johnson, Claus König, Jeff Marks, Town Peterson, Van Remsen, Tom Schulenberg, and Nathan Rice made valuable comments on the manuscript. We thank the following people and institutions (listed alphabetically by institution) for access to specimen material under their care: Robert Ridgely and David Agro (Academy of Natural Sciences [ANSP], Philadelphia), George Barrowclough and Paul Sweet (American Museum of Natural History [AMNH], New York), Robert Kennedy (Cincinnati Museum Center [CMC], Cincinnati), Greg Budney (Library of Natural Sounds, Cornell University, Ithaca, New York), David Willard (Field Museum of Natural History [FMNH], Chicago), David Steadman and Tom Webber (Florida Museum of Natural History [UF], University of Florida, Gainesville), Van Remsen and Steven Cardiff (Louisiana State University [LSUMNS], Baton Rouge), Raymond Paytner, Jr. (Museum of Comparative Zoology [MCZ], Harvard), Ned Johnson and Carla Cicero (Museum of Vertebrate Zoology [MVZ], University of California), Gary Graves (National Museum of Natural History, Smithsonian Institution), Bernal Rodríquez-H. (Universidad de Costa Rica [UCR], San José), and Sam Sumida (Western Foundation of Vertebrate Zoology [WFVZ], Camarillo, California).

\section{LiterATURE Cited}

AMERICAN ORnithologists' Union. 1998. Checklist of North American birds, 7 th ed. American Ornithologists' Union, Washington, D.C.

Best, B. J., T. Heijnen, and R. S. R. Williams. 1996. A guide to bird-watching in Ecuador and the Galápagos Islands. Biosphere Publications, West Yorkshire, United Kingdom.

Chapman, F. M. 1917. The distribution of bird-life in Colombia: A contribution to a biological survey of South America. Bulletin of the American Museum Natural History 36:1-729.

Chapman, F. M. 1926. The distribution of bird-life in Ecuador. Bulletin of the American Museum Natural History 55:1-784.

Collar, N. J., L. P. Gonzaga, N. Krabbe, A. MadROÑo Nieto, L. G. NARANJO, AND T. A. PARKer III. 1992. Threatened birds of the Americas. International Council for Bird Preservation, Cambridge, United Kingdom.

CRACRAFT, J. 1983. Species concepts and speciation analysis. Current Ornithology 1:159-187.

Dobson, C. H., AND A. H. Gentry. 1991. Biological extinction in western Ecuador. Annals of the Missouri Botantical Garden 78:273-295.

GómEZ, N. 1990. Atlas del Ecuador. Geografía y Economía. Ediguias C. Limidad, Quito, Ecuador.

HARDY, J. W., B. B. COFFEY, JR., AND G. B. REYNARD. 1990. Voices of the New World owls (Strigiformes: Tytonidae, Strigidae). ARA Records, Gainesville, Florida.

HeIDRICH, P., C. KÖNIG, AND M. WINK. 1995. Biakustik, Taxonomie und molekulare Systematik amerikanischer Sperlingskäuze (Strigidae: Glaucidium spp.). Stuttgarter Beiträge zur Naturkunde Serie A (Biologie) 534:1-47.

Howell, S. N. G., AND S. WebB. 1995. A guide to the birds of Mexico and northern Central America. Oxford University Press, New York.

Howell, S. N. G., AND M. B. RobBINS. 1995. Species limits in the Least Pygmy-Owl (Glaucidium minutissimum) complex. Wilson Bulletin 107:7-25.

Instituto Geografíco Agustín CodAzZI. 1989. Atlas básico de Colombia, 6th ed. Instituto Geográfico Agustín Codazzi, Bogota.

JOHNSON, N. K. 1980. Character variation and evolution of sibling species in the Empidonax difficilis-flavescens complex (Aves: Tyrannidae). University of California Publications in Zoology 112:1-151.

JOHNSON, N. K., AND J. A. MARTEN. 1988. Evolutionary genetics of flycatchers. II. Differentiation in the Empidonax difficilis complex. Auk 105:177191.

Kelso, L. 1937. A Costa Rican race of Jardine's Pygmy Owl. Auk 54:304.

KÖNIG, C. 1991. Zur Taxonomie und Ökologie der 
Sperlingskäuze (Glaucidium spp.) des Andenraumes. Ökologie der Vögel 13:15-76.

LANYON, W. E., AND S. M. LANYON. 1986. Generic status of Euler's Flycatcher: A morphological and biochemical study. Auk 103:341-350.

Malfait, J. A., AND M. G. Dinkleman. 1972. Circum-Caribbean tectonic and igneous activity and the evolution of the Caribbean plate. Geology Society of America Bulletin 83:251-272.

MAYR, E. 1963. Animal species and evolution. Harvard University Press, Cambridge, Massachusetts.

MAYR, E. 1969. Principles of systematic zoology. McGraw-Hill, New York.

MiLler, A. H. 1963. Seasonal activity and ecology of the avifauna of an American equatorial cloud forest. University California Publications in Zoology 66:1-78.

MORITZ, C. 1994. Applications of mitochondrial DNA analysis in conservation: A critical review. Molecular Ecology 3:401-411.

Peters, J. L. 1940. Check-list of birds of the world, vol. 4. Museum of Comparative Zoology, Cambridge, Massachusetts.

Phillips, A., J. Marshall, AND G. Monson. 1964. The birds of Arizona. University of Arizona, Press, Tucson.

Pindell, J., AND J. F. Dewey. 1982. Permo-Triassic reconstruction of Western Pangea and the evolution of the Gulf of Mexico/Caribbean region. Tectonics 1:179-211.

Ridgely, R. S., AND J. A. GWYNNE. 1989. A guide to the birds of Panama, with Costa Rica, Nicaragua, and Honduras, 2nd ed. Princeton University Press, Princeton, New Jersey.

RobBins, M. B., AND S. N. G. Howell. 1995. A new species of pygmy-owl (Strigidae: Glaucidium) from the eastern Andes. Wilson Bulletin 107:1-6.

Robbins, M.B., AND R. S. RIDGELy. 1990. The avifau- na of an Upper Tropical cloud forest in southwestern Ecuador. Proceedings of the Academy of Natural Sciences of Philadelphia 142:59-71.

RYDER, O. A. 1986. Species conservation and systematics: The dilemma of subspecies. Trends in Ecology and Evolution 1:9-10.

Salaman, P. G. W., AND F. G. Stiles. 1996. A distinctive new species of vireo (Passeriformes: Vireonidae) from the Western Andes of Colombia. Ibis 138:610-619.

Sibley, C. G., AND B. L. MonROE, JR. 1990. Distribution and taxonomy of birds of the world. Yale University Press, New Haven, Connecticut.

SLuD, P. 1964. The birds of Costa Rica: Distribution and ecology. Bulletin of the American Museum Natural History 128:1-430.

Smithe, F. B. 1975. Naturalist's color guide. American Museum Natural History, New York.

SMITHE, F. B. 1981. Naturalist's color guide, part III. American Museum Natural History, New York.

Stattersfield, A. J., M. J. Crosby, A. J. LONG, AND D. C. WEGE. 1998. Endemic bird areas of the world: Priorities for biodiversity conservation. BirdLife International Conservation Series No. 7, Cambridge, United Kingdom.

STEIN, R. C. 1958. The behavior, ecological, and morphological characteristics of two populations of the Alder Flycatcher, Empidonax traillii (Audubon). New York State Museum Science Service Bulletin No. 371.

Stiles, F. G., AND A. F. SKutch. 1989. A guide to the birds of Costa Rica. Cornell University Press, Ithaca, New York.

VielliARD, J. 1989. Uma nova especie de Glaucidium (Aves, / Strigidae) da Amazonia. Revista Brasileira Zoologia 6:685-693.

ZINK, R. M., AND M. C. MCKITRICK. 1995. The debate over species concepts and its implications for ornithology. Auk 112:701-719.

Associate Editor: J. S. Marks 